\title{
How Well can Healthcare Students Use Medical Collocations at both the Recognition and Production Levels? \\ https://doi.org/10.33806/ijaes2000.19.1.1
}

\author{
Shehdeh Fareh and Inaam Hamadi \\ University of Sharjah, UAE
}

\begin{abstract}
This study aimed at investigating healthcare students' collocational competence at the level of recognition and production. It was an attempt to provide answers to the following five questions: (1) How well can students recognize medical collocations? (2) How well can they produce them? (3) What types of mistakes do they make in recognizing and producing collocations? (4) Which type of collocation is the most difficult? (5) What implications to teaching English to healthcare students may this study have? Data were culled from a sample of 100 students through specially designed questionnaires for both recognition and production. It was found that the subjects' collocational competence was below expectations. Therefore, it was recommended that medical collocations be accorded systematic treatment in the process of teaching English to healthcare students.
\end{abstract}

Keywords: competence, healthcare, medical collocation

\section{Introduction}

Acquiring a functional knowledge of a language requires attaining an adequate mastery level in a number of language aspects that together lead to the development of communicative competence which encompasses the phonological, morphological, lexical, syntactic and pragmatic sub-competences. Furthermore, each of these components is composed of a number of skills or abilities that learners need to master in order to reach a satisfactory level in that subcompetence. One of the primary building blocks in language acquisition is the lexical competence which is manifest in learning the vocabulary of the language. Knowing a word involves knowing its pronunciation, spelling, part of speech, denotative and connotative meanings, collocations as well as its various derivative forms. Nation (1990:31) stated that knowing a word involves knowing its spoken form, written form, grammatical behavior, collocational behavior, frequency, stylistic register constraints, conceptual meaning and word associations. Shaw (2011:11) stated that knowledge of a word involves a few other aspects such as knowing its uses in context, the "semantic prosody" (positive or negative connotations), and the "semantic preference (the frequency of a word to occur with a specific semantic set)."

The lexicon of a language is the aspect that is usually subject to change due to the various social and technological changes occurring in communities. Each profession or academic field usually develops its own special set of terms or register such as the legal register, the medical register, and the register used in courts, etc. Consequently, language users in each profession need to learn how to 
use the terms that are commonly used in the variety of language they employ in their professions or fields of study in order to be able to communicate effectively and efficiently with each other. The ultimate goal of learning a word is to use it in both speaking and writing in culturally appropriate contexts. That is to say, the learner needs to use it in context with other words that may precede or follow it. This paper attempts to investigate the extent to which healthcare students are able to use medical collocations at both the receptive and productive levels.

The paper proceeds as follows. Section 2 below presents the objectives of the study and section 3 highlights its significance. The definition of the concept of collocation and a review of the related literature will be provided in section 4 . The methodology of the research will be explained in section 5. Finally, the findings, discussion, and implications will be presented in section 6 .

\section{Objectives of the study}

This study is an attempt to evaluate the collocational competence of healthcare students at the University of Sharjah. In other words, it examines the ability of these students to recognize medical collocations and produce them. More specifically stated, the study aims at providing answers to the following questions:

1. How well can students recognize medical collocations?

2. How well can they produce them?

3. What types of mistakes do they make in recognizing and producing collocations?

4. Which type of collocation is the most difficult?

5. What implications to teaching English to healthcare students may this study have?

\section{Significance of the study}

Vocabulary constitutes an essential component in the process of acquiring a foreign language because a learner will never be able to communicate in speaking or writing without having at his command an adequate level of lexical competence that comprises a number of sub-components. The collocational competence constitutes a major component of the learner's lexical competence. The learners' knowledge of collocations entails their ability to use words together properly in context. The proper use of collocations in speaking and writing indicates an acceptable level of language proficiency. McIntosh et al, (2009: vii)argue that an adequate knowledge of collocations renders students' performance in speech and writing "more natural, more native-speaker like, even when basic intelligibility does not seem to be at issue." Furthermore, Al- Ghazali (2015: 258) concluded that "If students are not aware of the potential combinations of an item, they will continue to struggle in listening and reading and more so in speaking and writing." On the other hand, the misuse of collocations may lead to misunderstanding or to communication breakdowns. This situation is aggravated because "lexical errors are the most frequent category of error" (James 1998:143). This finding is in harmony with the findings of earlier studies that reported that lexical errors outnumber other types of errors in foreign language learners' 
performance (see Grauberg 1971; Meara 1984). In this respect, James (1998:1523 ) holds that adhering to the collocational conventions of a foreign language effectively contributes to "idiomaticity and nativelikeness" whereas the opposite leads to foreignness or to "linguistic strangeness" as Crystal (1990: 13-14) described it. Therefore, learning collocations becomes of paramount importance to foreign language learners who may encounter difficulties in using colocations properly due to a number of factors, including the influence of their mother tongues, inadequate teaching methods, or inappropriate textbooks. This situation is aggravated by the fact that collocations are often overlooked in teaching foreign languages as Lewis (1997) put it “...although the structures of highly frequent verb patterns have formed, and still form, a key element of most language courses, other highly frequent word patterns- which is precisely what collocations are- have usually been ignored or at best been seen as marginal to courses" (p.256).

The inability to use the proper collocation results in using more words than needed, a matter that may result in unacceptable and verbose sentences. Hill (2000: 49) holds that "students tend to create longer utterances because they do not know collocations which express precisely what they want to say." Mistakes in the use of vocabulary in general and in the use of collocations in particular are liable to cause misunderstanding more than grammatical mistakes do. The high frequency and the gravity of errors in collocations motivated Hill (1999) to stress the importance of learning collocations and to suggest the term "collocational competence."

Foreign language learners' errors in lexis were reported to be the most severe and distorting to communication. McCretton and Rider (1993) conducted a study to rate the degree of gravity for the different types of error that foreign language learners commit. They ordered the errors according to the degree of gravity and provided the following hierarchy (181):

The most severe Least severe

Lexis $>$ spelling $>$ negation $>$ word order $>$ prepositions $>$ verb forms $>$ concord

These international studies clearly highlight the significance of learning collocations and stress the foreign language learners' need for developing collocational competence that enhances their ability to communicate and promotes the quality of their writing.

\section{Review of the related literature}

It might be expedient at the outset to define the term collocation. Collocation is a syntagmatic relation that holds between a word and the other words that can precede or follow it. Different scholars have defined this term as the tendency of words to co-occur with each other. It is not an exaggeration to say that words in all languages co-occur with each other. The notion of collocation was first proposed by Palmer (1933), who stated that "each collocation... must or should be learnt as an integral whole or independent entity, rather than by the process of piecing together their component parts." This concept was later brought up to 
theoretical linguistics by Firth (1957:11), who stated that "You shall know a word by the company it keeps." More recently, the notion of collocation and its significance to language learning and teaching were further developed by other scholars such as Lewis (1997) and Robins (2000). According to Lewis (2000:8) collocation is "the readily observable phenomenon whereby certain words cooccur in natural text with greater than random frequency." Moreover, Robins (2000:64) defined it as "the habitual association of a word in a language with other particular words in sentences." McCarten (2007:5) describes the term collocation as the "the way in which two or more words are typically used together." For example we say "large intestines' but not "big intestines" and "administer a drug" but not a "administer food."

The study of vocabulary in general and collocations in particular has gained momentum in the field of foreign language learning over the past few decades. For example, Nattinger and DeCarrico (1992) and Lewis (1993) investigated the frequency of formulaic sequences, including idioms, discourse markers as well as collocations and the role that they play in foreign language learning. Mastering these sequences plays a vital role in developing learners' communicative competence and enabling them to use the language functionally and native likely (see Nation 2001; Barfield and Gyllstad 2009). Lafford et al. (2000) investigated the acquisition of lexical meaning by Spanish learners of other languages. They discussed a number of focal issues pertaining to how the lexical competence is determined, how the lexicon is acquired and organized, in addition to why studying second language vocabulary is important. Duan and Qin (2012) conducted a study in which they stressed the importance of teaching collocations to Chinese students. The researchers also examined the types of error that intermediate Chinese learners encounter in learning English collocations. They found out that most of the collocation errors were mainly attributed to L1 negative transfer and overgeneralization. Duan and Qin concluded their research by proposing a number of recommendations for teaching collocations to foreign language learners. Many other studies were conducted to explore the collocational competence of non-native speakers. Takac and Miscin (2013), for example, conducted a study to investigate the collocational competence of Croatians studying medical English. The research aimed at evaluating how well students of medicine can use medical collocations, especially verb collocations that consist of a verb and a noun in order to determine the weaknesses and difficulties that students encounter. The ultimate purpose of this study was to suggest techniques for teaching collocations to those students. The research was conducted on a sample of 50 first year students, 51 fifth-year students and 26 doctors. One of the aims of the study was to compare the levels of collocational competence among the three groups. The findings revealed a significant difference between the performances of the three groups. It was also found that certain collocations are more difficult than others. The researchers concluded that collocations constitute a major difficulty for non-native speakers of English. The difficulties were attributed to heavy reliance on the students' mother tongue. It was also found that "the continuous exposure to and active use of medical collocations increase the 
knowledge of collocations" (250). Although this study was well-conducted, it only focused on verb-noun collocations and did not deal with adjective-noun collocations which are also common in medical English. Furthermore, the difficulty that students encounter in using medical collocations was mainly attributed to negative transfer from the students' mother tongue. Other possible causes such as the teaching method and the textbooks used were not even proposed.

Another study was conducted by Stefic et al.( 2010) for the purpose of comparing and contrasting the meanings of dental collocations in Croatian and English. The findings revealed certain differences between dental collocations in the two analyzed languages. It was also found that there was no symmetry between the structures of the languages. Finally, it was concluded that "identifying collocations in technical language is essential for their understanding and accurate translation into another language" (p.187).

Two more studies are worth reviewing in this context. Laso and John (2013) investigated the non-native speakers' awareness of the use of collocations in their writings. The sample of the study consisted of 24 Spanish practicing doctors who were required to write and publish research in English. The findings of the study revealed that the subjects were aware of some of the common collocational patterns in which they were tested, but they still needed more support in using other collocational patterns. The researchers concluded their paper with some recommendations for teaching and learning collocations. This study clearly revealed that the use of collocations presented difficulty for healthcare professionals as well as students. It also highlighted the significance of the proper use of collocations in writing.

Secondly, Takac and Miscin (2013) conducted a study to determine the most frequent verb-noun collocations in medical English and to evaluate the extent to which first-year medical English students can recognize and use them. The findings revealed that the most frequent verbs used in collocations were "cause, have, develop, treat (with), prevent, produce, assess, check, evaluate, diagnose, alleviate, decrease, reduce, and relieve." It was found that recognizing collocations was easier than producing them. The translation of collocations from English into Croatian and vice versa was the most difficult task in the test. In light of the findings, the researchers stressed the need for teaching and learning collocations, which as they stated, are "the important aspects of L2 performance" (615).

Having reviewed a number of studies on the acquisition of collocations in general and the acquisition of medical collocations in particular, we can conclude the following. Learning medical collocations is essential for natural communicating in both speech and writing. Medical collocations present a serious difficulty to foreign language learners. Misusing collocations usually results in vague and verbose, stylistically unacceptable sentences, if not meaningless. There is a dire need for a systematic introduction of collocations to healthcare students throughout their course of study in their colleges. Continuous 
and systematic teaching of medical collocations will inevitably improve students' performance in language.

The present study aims at evaluating the collocational competence of healthcare students at both the receptive and productive levels. Unlike the reviewed studies that examined one type of collocations, this study investigated three types of collocations at both the recognition and production levels. Furthermore, most of the previous studies focused on developing methods to teach collocations. The sample sizes were also less than the sample size in this study. Another important difference between this study and the reviewed ones is manifest in the data elicitation techniques at both the receptive and the productive levels. This study employed four different techniques for eliciting data at both production and reception levels.

\section{Methodology}

\subsection{Sample}

Data for this study were culled form 100 students studying medical English from different healthcare specializations, including medicine, pharmacy, dentistry, health sciences, nursing, laboratories, radiology, physiotherapy and nutrition. Four sections consisting of 115 students were randomly selected for the purpose of this study. At the time of collecting data, the students were in the last week of the second semester. This means that they have already studied the course titled English for Medical Sciences and satisfied the university admission requirement of obtaining a score of 500 on the TOEFL or a band score of 5 on the IELTS. Furthermore, all the subjects had successfully completed a course titled English for Academic Purposes, which is a university compulsory course. The sample included both males and females.

\subsection{Data elicitation}

Two specially designed tests were employed to collect data from the subjects. The first one was designed to measure the students' ability to recognize medical collocations, whereas the second one was used to evaluate the students' competence of producing medical collocations. Three types of collocations were used in the test: verb-noun collocations, adjective-noun collocations, and verbpreposition collocations. Verb-noun collocations such as "administer a drug" are the most frequent in the language used in the healthcare professions (Takac \& Miscin 2013). In order to obtain a comprehensive evaluation of the students' collocational competence, and to determine which type of collocation is more difficult, the researchers designed a special section consisting of ten adjectivenoun collocations such as "runny nose" and another one comprising ten verbpreposition collocations such as "diagnosed with".

\subsubsection{Recognition test}

In order to evaluate the collocational competence of the subjects at the recognition level, a test consisting of four parts was designed (Appendix 1). Part one comprised 40 multiple choice items in which students were asked to select the 
most appropriate collocate that fills in the blank space in each sentence. Forty common collocations were selected from a number of textbooks used for teaching English to healthcare students. Each collocation consisted of a verb and a noun. The purpose of this part was to evaluate the subjects' ability to identify the correct verb that best completes the collocation in each sentence.

Part 2 of the recognition test comprised ten items in each of which there is a mistake or an unacceptable collocation. The students were asked to underline the mistake and correct it. The purpose of this part is to check whether or not the subjects were able to detect erroneous collocations of any type of the three mentioned above.

Part 3 of the recognition test consisted of 10 multiple choice items in which the subjects were asked to select the most appropriate preposition that collocates with each verb in the stem. The aim of this task was to assess the subjects' ability to recognize verb-preposition collocations.

Part 4 comprised 10 matching items to evaluate the subjects' ability to recognize adjective-noun collocations. The subjects were given a list of 10 adjectives and another list of 10 nouns, and they were asked to select the noun that collocates with each adjective.

To sum up, the recognition test consisted of four components with a total of 70 collocations distributed as follows:

- Forty multiple choice items of the verb-noun collocation type,

- Ten mixed error-detection items,

- Ten verb-preposition multiple choice items,

- Ten adjective-noun matching items.

\subsubsection{Production test}

This test was designed in order to evaluate the subjects' collocational competence at the level of production. It consisted of four parts (Appendix 2). Part 1 was a translation task in which the subjects were asked to translate 40 Arabic sentences into English. Each sentence contained a verb-noun collocation. The focus of the translation was on whether or not the subjects were able to get the acceptable collocation in English. Mistakes in grammar and spelling were ignored.

Part 2 comprised 15 fill-in the blank items in which the subjects were asked to fill in the blank space in each sentence with the verb that best completes the collocation. A list of 15 verbs was given at the beginning of the task from which the subjects were asked to select. This task required the subjects to understand the meaning of each verb and the context in which it is used.

Part 3 consisted of 10 fill-in the blank items in which the subjects were asked to fill in the blank space in each sentence with the adjective that best completes the adjective-noun collocation. A list of 10 adjectives was provided at the beginning of the task. The purpose of this task was to assess the subjects' competence in producing adjective-noun collocations. 
Finally, part 4 consisted of 10 fill-in the blank items in which the subjects were asked to fill in the blank in each sentence with the preposition that best completes the collocation. A list of 10 prepositions was provided at the beginning of the task from which the subjects were asked to select.

In brief, the production test consisted of four components with a total of 75 collocations distributed as follows:

- Translation: the subjects were asked to translate into English 40 Arabic sentences with a collocation in each,

- Fifteen fill-in the blank verb-noun items,

- Ten fill-in the blank adjective-noun items,

- Ten fill-in the blank verb-preposition items.

It is worth mentioning that the production test was administered before the recognition part in order to avoid any washback effect, i.e. the effect of testing on learning.

\section{Findings}

\subsection{Recognition}

The collocational competence of healthcare students to recognize medical collocations was evaluated through four techniques as stated above. Table (1) below presents the means and percentages of the subjects' correct responses on the four tasks of the recognition elicitation technique.

Table 1: Means and percentages of correct answers at the recognition level

\begin{tabular}{|l|l|l|l|l|l|}
\hline Task & & Frequency & $\begin{array}{l}\text { Mean } \\
\text { of } \\
\text { correct } \\
\text { answers }\end{array}$ & \% & SD \\
\hline Gap-fill & a. Verb+ Noun & 40 & 28.9 & 72.3 & 5.1 \\
\hline & b. Adj.+ Noun & 10 & 6 & 60 & 2.1 \\
\hline & $\begin{array}{l}\text { a. Verb+ } \\
\text { preposition }\end{array}$ & 10 & 5.5 & 55.5 & 1.3 \\
\hline Error Detection & & 10 & 5.1 & 50.6 & 5.4 \\
\hline Total & & 70 & 45.5 & 59.6 & \\
\hline
\end{tabular}

A quick glance at Table (1) reveals that the overall percentage of the correct responses of the subjects on the four tasks is $59.6 \%$ which is rather low and unsatisfactory taking into consideration the fact that the subjects have already successfully fulfilled the university admission requirement of obtaining an IELTS 
band score of 5 or a score of 500 on the TOEFL. Moreover, the students have completed two courses in English: English for Academic purposes and English for Medical Students. They have also studied biology, chemistry and other foundation courses in English. The percentage of correct responses means that more than $40 \%$ of the students encounter a considerable difficulty in recognizing medical collocations in general. Given the fact that the proper use of collocations in writing and speaking effectively contributes to the quality of communication, one can imagine how inadequate and ineffective the collocational competence of the students is. This low level of collocational competence entails that the students' ability to communicate in both writing and speaking is expected to be seriously defective and inadequate. High quality writing and speaking involve appropriate word choice and effective use of word strings or collocations.

Table (1) also reveals that the most difficult test part for the students was the one in which they were asked to detect the mistakes in ten sentences. The percentage of correct responses in the error-detection task was 50.6\%. This indicates that almost half of the students encountered a noticeable difficulty in recognizing unacceptable collocations. The second most difficult part was manifest in the students' ability to recognize collocations consisting of verb+ preposition. The percentage of correct responses was 55.5 with a mean of 5.5 and a standard deviation of 1.3 . This percentage is very low because $44.5 \%$ of the students were unable to recognize the unacceptable verb-preposition collocation. The third most problematic area was the adjective-noun collocations where the percentage of correct responses was $60 \%$ with a mean of 6 and a standard deviation of 2.1.

Finally, the least difficult area is the verb-noun collocations. Although the percentage of correct responses is relatively high (72.3\%), compared with those of the other collocation types, it remains inadequate since more than $27 \%$ of the students face difficulty in recognizing this type of collocation. The relative ease of this collocation may be attributed to the fact that verb-noun collocations are more frequent and more commonly used in the healthcare fields.

Table (2) below shows the most difficult verb-noun collocations and the erroneous responses the students used. 
Table 2: The most difficult verb-noun collocations at the recognition level

\begin{tabular}{|c|c|c|}
\hline No. & Target collocation & Wrong response \\
\hline 1 & administer a drug & describe a drug \\
\hline 2 & analyze the effects & determine the effects \\
\hline 3 & alleviate the pain & decrease the pain, release the pain. \\
\hline 4 & take effect & send effect, give effect \\
\hline 5 & make a full recovery. & $\begin{array}{l}\text { manage a full recovery, obtain a } \\
\text { full recovery }\end{array}$ \\
\hline 6 & reduce the swelling & decrease the swelling \\
\hline 7 & contracted the corona virus & $\begin{array}{l}\text { impacted the corona virus, } \\
\text { attracted the corona virus. }\end{array}$ \\
\hline 8 & ease labor pain & release labor pain. \\
\hline 9 & gain weight & increase weight. \\
\hline 10 & operated on ... & diagnosed on .... \\
\hline 11 & prescribe you something & describe you something \\
\hline 12 & regained consciousness & returned consciousness \\
\hline 13 & transmitted the aids & transported the aids \\
\hline 14 & suppress a cough & depress a cough \\
\hline 15 & tolerated the pain & alleviated the pain \\
\hline 16 & sought medical help & brought medical help \\
\hline 17 & sprained his right ankle & sustained his right ankle \\
\hline 18 & dress the patients wound & suppress the patients wound \\
\hline 19 & endanger the patient's life & threat the patient's life \\
\hline 20 & probed the wound & stitched the wound \\
\hline 21 & adjust the dosage & amend the dosage \\
\hline
\end{tabular}

These examples of erroneous responses indicate that a considerable percentage of the students could not recognize the components of verb-noun collocations, a 
matter which negatively impacts the quality of their performance in both writing and speaking. Their writing and speech is expected to be wordy, verbose and full of redundancies because if a student is unable to use the correct collocation, he will paraphrase it in his own words, using more words than needed. Consequently, students' performance will be awkward or unintelligible. Moreover, it can also be readily concluded that medical collocations were not focused on in the process of teaching English to healthcare students, nor were they accorded proper attention in textbooks.

Casting a quick glance at the erroneous responses of the subjects, one can detect the impact of L1 negative transfer. For example, the verb 'prescribe' was replaced with 'describe' because it is the nearest equivalent to the Arabic verb used in such a collocation, which is 'wasafa,' the Arabic collocation equivalent to 'prescribe a drug' in English. The same can be said about the erroneous use of 'transported and increased' instead of 'transmitted and gained' respectively in the collocations 'transmit a disease' and 'gain weight.' More examples of L1 negative transfer can also be noticed in the use of 'amend, return and threat' instead of 'adjust, regain and endanger.'

These instances of negative transfer indicate that the students resort to their mother tongue to find synonyms or nearest equivalents in cases of incongruence between English and Arabic. This may explain the use of the verbs increase, amend, return, and threat instead of the target verbs gain, adjust, regain, and endanger, respectively. The use of synonyms from the learners' mother tongue as a strategy usually leads to producing miscollocations. This is also evident in the production tasks as will be noticed later. This finding is compatible with the findings of earlier studies in this respect (see: Guo, 2009; Zughoul and AbdulFattah 2001).

Having examined the collocational competence of the students at the recognition level, it might be expedient at this point to turn to their competence at the production level.

\subsection{Production}

The ability of healthcare students to use medical collocations in writing was assessed through four tasks as stated earlier. Table (3) below summarizes the performance of the subjects in the four tasks. 
Table 3: Means and Percentages of correct responses at the production level

\begin{tabular}{|c|c|c|c|c|c|}
\hline Task & & Frequency & $\begin{array}{l}\text { Mean } \\
\text { of } \\
\text { correct } \\
\text { answers }\end{array}$ & $\%$ & SD \\
\hline \multirow[t]{3}{*}{ Gap-fill } & a. Verb+ Noun & 15 & 9.5 & 63 & 4.6 \\
\hline & b. Adj.+ Noun & 10 & 4.9 & 48.8 & 2.4 \\
\hline & $\begin{array}{ll}\text { c. } & \text { Verb+ } \\
\text { preposition }\end{array}$ & 10 & 4.7 & 47 & 1.3 \\
\hline Translation & & 40 & 16.4 & 41 & 7.3 \\
\hline Total & & 75 & 35.5 & 47.3 & \\
\hline
\end{tabular}

Table (3) clearly shows that the mean of correct responses in the four parts of the production test is 35.5 and the percentage is 47.3 . This level of performance is rather low and unacceptable because $53 \%$ of the students seem to encounter a serious problem in using medical collocations taking into consideration that the students have already met the university admission requirement regarding the proficiency in English. It is also obvious that the most difficult task was the translation part in which the subjects were asked to translate 40 sentences from Arabic into English where each sentence includes a collocation. The average of correct responses in the translation task is 16.4 which is equal to $41 \%$. This means that $59 \%$ of the students did not do well on this task that required them to produce an appropriate collocation in English. This finding supports Takac and Miscin's (2013) finding that translation from English into Croatian and vice versa was the most difficult task in the test and recognizing collocations was easier than producing them. Table (4) bellow indicates the wrong translations for most of the 40 English collocations.

Table (4): Erroneous translations of medical collocations

\begin{tabular}{|l|l|l|}
\hline No. & Target collocation & Wrong translation \\
\hline 1 & administer drugs & render drugs, give medicine, prescribe drugs \\
\hline 2 & amputate a finger & $\begin{array}{l}\text { take off his finger, amputate toe, resect } \\
\text { finger/ toes }\end{array}$ \\
\hline 3 & alleviate the pain & sooth the pain, relief the pain, \\
\hline 4 & make a full recovery & $\begin{array}{l}\text { expected the fully recovery, expect the } \\
\text { patients will recover completely, obtain the }\end{array}$ \\
\hline
\end{tabular}




\begin{tabular}{|c|c|c|}
\hline & & full recovery \\
\hline 5 & take effect & begin effect, start to give effect, take action \\
\hline 6 & reduce the swelling & $\begin{array}{l}\text { reduce the tumor, deflate the swelling, } \\
\text { remove the swelling, decrease the swelling }\end{array}$ \\
\hline 7 & contract the corona virus & $\begin{array}{l}\text { infected with corona virus, had corona virus, } \\
\text { injured with virus }\end{array}$ \\
\hline 8 & cure diseases & treat the disease, treat the patient \\
\hline 9 & deliver a healthy baby & $\begin{array}{l}\text { have a healthy baby, give birth to a healthy } \\
\text { baby, have a normal child }\end{array}$ \\
\hline 10 & detect pathogens \germs & $\begin{array}{l}\text { know the germs, discover the germs, } \\
\text { recognize the germs }\end{array}$ \\
\hline 11 & develop asthma & $\begin{array}{l}\text { infected with asthma, obtain asthma, injured } \\
\text { crisis, affected with asthma }\end{array}$ \\
\hline 12 & discontinue the treatment & $\begin{array}{l}\text { stop the treatment, stop the medicine, stop } \\
\text { the therapy }\end{array}$ \\
\hline 13 & ease labor pains & reduce the childbirth pain, \\
\hline 14 & gain weight & increase weight \\
\hline 15 & check my pulse & $\begin{array}{l}\text { measure my heart beat, made pulser, } \\
\text { test my pulse }\end{array}$ \\
\hline 16 & inject insulin & take insulin \\
\hline 17 & $\begin{array}{l}\text { operate on suspected } \\
\text { acute appendicitis }\end{array}$ & resect the appendix, to remove appendix, \\
\hline 18 & $\begin{array}{l}\text { prescribe a medicine for a } \\
\text { dry cough }\end{array}$ & $\begin{array}{l}\text { describe a medicine for dry cough, start a } \\
\text { medication, distract medicine for dry cough }\end{array}$ \\
\hline 19 & receive a healthy kidney & $\begin{array}{l}\text { takelget a healthy kidney, give a healthy } \\
\text { kidney }\end{array}$ \\
\hline 20 & regain consciousness & $\begin{array}{l}\text { got his awake, return consciousness, ready } \\
\text { consciousness }\end{array}$ \\
\hline 21 & transplant a kidney & cultivate a kidney, transport a kidney \\
\hline 22 & transmit aids virus & $\begin{array}{l}\text { transported aids virus, transferred the } \\
\text { disease }\end{array}$ \\
\hline
\end{tabular}




\begin{tabular}{|l|l|l|}
\hline 23 & $\begin{array}{l}\text { underwent a surgical } \\
\text { dialysis }\end{array}$ & blood washing \\
\hline 24 & suppress a cough & $\begin{array}{l}\text { reduce an activity of dry cough, depress his } \\
\text { allergic cough }\end{array}$ \\
\hline 25 & tolerate the pains & $\begin{array}{l}\text { detrained chemical treatment pains, endured } \\
\text { the painltolerated the chemical therapy }\end{array}$ \\
\hline 26 & seeklsought medical help & $\begin{array}{l}\text { brought medical help, request medical help, } \\
\text { asked for help }\end{array}$ \\
\hline 27 & sprainlsprained his ankle & injured his foot, strained his ankle \\
\hline 28 & treat gum infections & treat gum inflammation, treat gum teeth \\
\hline 29 & suffer a heart attack & got stroke, had thrombosis \\
\hline 30 & refer to a cardiologist & $\begin{array}{l}\text { refer to heart specialist, transfer to } \\
\text { cardiologist }\end{array}$ \\
\hline 31 & burp a baby & help children in bleaching \\
\hline 32 & dress the patient's wound & treat the patient wound \\
\hline 33 & endanger the patient's life & $\begin{array}{l}\text { threat the patient's life, exposure the } \\
\text { patient's life to risk, affect the patient life }\end{array}$ \\
\hline 34 & probe the wound & $\begin{array}{l}\text { explored the wound, stitched the wound, } \\
\text { diagnosed the wound with a scalpel, discover } \\
\text { the wound scalpel }\end{array}$ \\
\hline 35 & bruise her knee & got injured, squeezed her knee, sooth the rash \\
\hline 36 & sooth the rash & $\begin{array}{l}\text { relieve irritation, remove the pain, decrease } \\
\text { the redness }\end{array}$ \\
\hline 37 & adjust the dosage & $\begin{array}{l}\text { amend the dosage, fix the dosage, reduce the } \\
\text { dose, change the amount of medicine }\end{array}$ \\
\hline
\end{tabular}

The next most difficult production task that students encountered was the use of verb-preposition collocations. The percentage of correct responses was $47 \%$. This means that $53 \%$ of the students were unable to select the correct preposition that collocates with certain verbs commonly used in healthcare fields. Verb-preposition collocations constitute a real problem not only for students in medical specializations but also for students learning English as a foreign or second language as well. In this respect, Lessard-Clouston (1993: 5) argued that phrasal verbs constitute a "significant learning task for students learning English 
as a foreign or second language." This is due to a number of factors pertaining to whether these multi-word verbs are interpreted literally or idiomatically. Furthermore, some phrasal or prepositional verbs may have more than one meaning.

The third most difficult task was the production of adjective-noun collocations. The percentage of correct responses was $48.8 \%$. The performance of students in this task was very low since more than $51 \%$ of the subjects were unable to match the adjective with the noun it collocates with. Finally, the least difficult task was the production of verb-noun collocations where the percentage of correct responses was $63 \%$. Although the students' performance in this part is relatively higher than their performance in the other three components, it is still below expectations because of the reasons given earlier.

Finally, it has become obvious that the students' results on the recognition tasks are compatible with those on the production tasks in terms of difficulty. That is to say, the most difficult collocations to recognize were also the most difficult to produce. For example, the verb-noun collocations were the least difficult type of collocation for the students to recognize and produce as well. However, the verb-preposition collocations were the second most difficult type of collocations to recognize and produce. In general, what was easier to recognize was also easier to produce.

\subsection{Discussion and implications}

It has become evident that the collocational competence of the students is low and below expectation at both the recognition and the production levels. Comparing the responses of the subjects in the recognition tasks with those in the production, we can readily notice that the percentage of correct responses in recognition $(59.6 \%)$ was higher than that of production $(47.3 \%)$. This variation may be attributed to the fact that comprehension or recognition usually develops earlier than production. In addition, what students know is usually more than what they can use. This finding corroborates what Brown (2000:33-4) stated that “... most observational and research evidence points to the general superiority of comprehension over production, and "... even adults perceive more syntactic variation than they actually produce."

The findings indicate that healthcare students face a serious difficulty in attaining an adequate level of mastery in recognizing and using medical collocations of all types. The overall mastery level of both recognition and production is $53.45 \%$. This low level of performance is far from being adequate because the subjects of the study have already fulfilled the university admission requirements regarding attaining a band score of 5 on the IELTS exam or a score of 500 on the TOEFL. In addition, they have also completed a course on English for Academic Purposes as well as two or more content courses taught in English. Misusing medical collocations in writing implies awkward and verbose compositions; a matter which lowers the quality of writing be it in research, referral letters or medical reports. 
This inadequate level of collocational competence motivates us to conclude that there is a methodological deficiency in the practices of teaching English for healthcare students at the tertiary level. Furthermore, we should not ignore the role of textbook authors and curriculum designers who should accord more attention to teaching medical collocations to students. It is, therefore, advisable that the teaching process be reconsidered and the teaching materials be redesigned in a way that focuses more on raising students' awareness of the importance of properly using medical collocations in their speech and writing. Moreover, relevant teaching activities that aim at developing the collocational competence of learners at the level of production should be provided. Students need to be provided with reading comprehension texts that are rich in medical collocations in order to raise their awareness of such multi-word units and to enable them to use them efficiently. The techniques used in assessing students' performance in English should also contain questions that test students' collocational competence. The outcomes of these practices are expected to contribute positively to the development of the entire lexical competence of the learners.

Casting a look at the errors that the subjects committed at the recognition level, we can easily notice that the subjects are not aware of the existence of collocations. Very often, they erroneously selected verbs that are close in meaning to the correct verbs in the collocations as in 'increase weight' instead of 'gain weight', 'return consciousness' instead of 'regain consciousness', 'depress a cough' instead of 'suppress a cough' and 'amend the dosage' instead of 'adjust the dosage.'

Their erroneous productions were also similar to their mistakes in recognition. In the translation process, they used 'render a drug' instead of 'administer a drug', 'take off a finger' instead of 'amputate a finger', 'expect a full recovery' instead of 'make a full recovery', deflate the swelling' instead of 'reduce the swelling' and 'transfer to a cardiologist' instead of 'refer to a cardiologist.'

The mistakes that the subjects committed in recognizing and producing verb-preposition collocations were mainly manifest in replacing a preposition with another one. For example, they used 'pick out/on/off the disease' instead of 'pick up...', 'get off the illness' instead of 'get over...' and 'cured her from the disease' instead of 'cured her of....'

Similarly, most of the erroneous responses of the subjects' in recognizing and producing adjective-noun collocations were manifest in the wrong use of adjectives with the nouns with which they collocate. For example, they used 'allergic tumor' instead of 'benign tumor', 'incipient reaction' instead of 'allergic reaction', and 'a defective disease' instead of 'a lethal disease', etc.

The high frequency of errors in recognizing and producing collocations of all types highlights the need for raising students' awareness of the significance of the proper use of collocations in their speech and writing. Therefore, it is recommended that collocations be accorded systematic attention in teaching English to healthcare students. Special sections in textbooks must be devoted to developing the collocational competence of learners rather than focusing on 
individual lexical items and grammatical structures. In this respect, Lewis (1993:89) holds that "lexis is the core of language while grammar plays a subservient role." This entails according more attention to teaching lexical chunks, including collocations to foreign language learners. Furthermore, methods of assessing students' performance in English should include components that assess the students' collocational competence. These recommendations corroborate Vasiljevic's (2008:46-50) finding that "Explicit teaching of collocations can help students not only acquire new words, but also develop their productive knowledge of previously met words, significantly reducing the frequency of output errors in students' speech and writing."

Shehdeh Fareh (PhD. Corresponding author)

University of Sharjah, UAE

Email: shfareh@sharjah.ac.ae

Inaam Hamadi (MA)

University of Sharjah, UAE 


\section{References}

Ghazali Al, Fawzi. (2015). 'Reinforcing students' collocational competence in EFL classrooms'. MJAL,7 (3): 244-261.

Barfield, A. and H. Gyllstad. (2009). Researching Collocations in another Language: Multiple Interpretations. Basingstoke: Palgrave McMillan.

Brown, H. Douglas. (2000). Principles of Language Learning and Teaching. ( $4^{\text {th }}$ ed. $)$. New York: Longman.

Crystal, David. (1990). 'Linguistic strangeness'.www.davidcrystal.com/?fileid=$\underline{4279}$ (Retrieved on July 11, 2016).

Duan, Manfu and Xiaohui Qin. (2012). 'Collocation in teaching and learning English'. Theory and Practice in Language Studies, 2 ( 9): 1890-1894.

Firth, J. R. (1957).'Modes of meaning.' In F.R. Palmer (ed.), Papers in Linguistics, 190-215. London: Oxford University Press.

Grauberg, W. (1971). 'An Error analysis of German in first-year university Students'. In G. Parren and J. I. M. Trim (eds.). Applications of Linguistics, 257-63.Cambridge: Cambridge University Press.

Guo, C. (2009). 'An analysis of the use of collocations by intermediate EFL college students in Taiwan'. ARECLS, 6: 141-155.

Hill, J. (1999). 'Collocational competence'. English Teaching Professional, 11: 3-6.

Hill, J. (2000). 'Revising priorities: from grammatical failure to collocational success'. In Michael Lewis (ed.), Teaching Collocation: Further Developments in the Lexical Approach, 47-69. Croatia: Heile.

James, Carl. (1998). Errors in Language Learning and Use: Exploring Error Analysis. London: Longman.

Lafford, Barbara A., Joseph Collentine and Adam Karp. (2000). 'The Acquisition of lexical meaning by second language learners: An analysis of general research trends with evidence from Spanish.'http://www2.nau.edu/ jgc/research/vocabstate/index.htm (Retrieved on May 20, 2016).

Laso, Natalia and Suganthi John. (2013). 'An Exploratory study of NNS medical writers' Awareness of the collocational patterning of abstract nouns n medical discourse'. RESLA, 26: 307-331.

Lessard-Clouston, M. (1993). 'Catching on: understanding phrasal verbs for ELT'. ELI Teaching: A Journal of Theory and Practice, 15: 5-9.

Lewis, Michael. (1993). The Lexical Approach: The State of ELT and the Way Forward. Hove, England: Language Teaching Publications.

Lewis, Michael. (1997). 'Pedagogical implications of the lexical approach'. In James Coady \& Thomas Huckin (eds.). Second Language Vocabulary Acquisition, 255-270. Cambridge: Cambridge University Press.

Lewis, Michael. (Ed.) (2000). Teaching Collocation: Further Developments in the Lexical Approach. Hove, England: Language Teaching Publications. 
McCarten, Jeanne. (2007). Teaching Vocabulary: Lessons from the Corpus, Lessons for the Classroom. Cambridge: Cambridge University Press

McCretton, E. and N. Rider. (1993). 'Error gravity and error hierarchies'. International Review of Applied Linguistics, 31: 177-88.

McIntosh, C., B. Francis, and R. Poole. (2009). Oxford Collocations Dictionary for Students of English. Oxford: Oxford University Press.

Meara, P. (1984). 'The Study of Lexis in Interlanguage'. In A. Davis, C. Cripper and A. P. R. Howatt (eds.). Interlanguage: Papers in Honour of S. Pit Corder, 225-35.Edinburgh: Edinbourgh University Press.

Nation, Paul. (2001). Learning Vocabulary in another Language. Cambridge: Cambridge University Press.

Nation, Paul. (1990). Teaching and Learning Vocabulary. New York: Newbury House.

Nattinger, James R. and DeCarrico S. (1992). Lexical Phrases and Language Teaching. Oxford: Oxford University Press.

Palmer, H. (1933). Second Interim Report on English Collocations. Tokyo: Kaitakusha.

Robins, R. H. (2000). General Linguistics. (4 ${ }^{\text {th }}$ ed.). Beijing: Foreign Language Teaching and Research Press.

Shaw, Erin M. (2011). 'Teaching Vocabulary Through Data-driven Learning'. http://scholarsarchive.byu.edu/etd (Retrieved on July 20, 2016).

Stefic, Lidija, Marinka Mravak-Stipetic and Vesna Boric. (2010). 'Collocations in the language of dental medicine: examples in oral medicine'. Acta Stomatol croat, 44 (3):176-187.

Takac, Visnja Pavicic and Evelina Miscin. (2013). 'Exploring the collocational competence of non-native users of medical English'. JAHR, 4 (7): 235-256.

Vasiljevic, Zorana. (2008). 'Developing collocational competence of second language learners'. The East Asian Learner, 4 (1): 46-50.

Zughooul, Mohammad. R. and Hussain Abdul Fattah. (2001). 'Collocational Competence of Arabic Speaking Learners of English: A study in lexical semantics'. http://files.eric.ed.gov/fulltext/ED479650.pdf (Retrieved on July 15/2016). 


\section{Appendices}

\section{Recognition tasks}

\section{A. Circle the letter of the correct answer that best completes each of the following sentences.}

1. Paramedic crews can
a. render
b. administer
c. decide
d. describe drugs to patients in emergency cases.

2. The medical team decided to
a. recover
b. cure
c. diagnose
d. amputate

3. The cardiologist was requested to the patient's finger. operation to the patient's relatives.
a. determine
b. examine
c. analyze
d. diagnose

4. Take two tablets now. They will the effects of the surgical
a. release
b. decrease
c. alleviate the pain quickly.

5. It was a simple recovery and the doctors expected the patient to a full recovery.
a. do
b. manage
c. make
d. obtain

6. You will feel better when the painkillers start to effect.
a. send
b. take
c. force
d. give

7. The doctor could not put the patient's arm in a plaster because he had to the swelling.
a. deflate
b. decrease
c. reduce
d. remove

8. Many nurses the corona virus while they were touring camps in Africa.
a. attracted
b. distracted
c. impacted
d. contracted

9. Physicians usually try many methods to
a. cure
b. alleviate
c. kill diseases.

10. A lady can always a healthy baby if she is under forty years of age.
a. carry
b. bring up
c. deliver
d. manage

11. They created medical surfaces that can
a. predict
b. test
c. diagnose
d. detect pathogens.

12. People who work in chemical industries usually asthma at an early age.
a. obtain
b. receive
c. develop
d. contract

13. The patient was advised to the treatment after two months.
a. cut
b. discontinue
c. reject
d. discharge

14. In some parts of the world, dried shark brain is used to labor pains, and prevent tooth decay.
a. release
b. wheeze
c. freeze
d. ease

15. Diabetic patients usually weight. 

a. regain
b. increase
c. obtain
d. gain

16. As soon as the doctor came to see me, he my pulse.
a. checked
b. took
c. diagnosed
d. predicted

17. Patients with type A diabetes learn to
a. infuse
b. inject
c. intake

insulin by themselves.

18. The doctors on suspected acute appendicitis.
a. diagnosed
b. operated
c. detected
d. checked

19. The doctor may you something for that dry cough.
a. describe
b. assign
c. decide
d. prescribe

20. Hopefully, the patient will a healthy kidney during the transplant.
a. take
b. obtain
c. perceive
d. receive

21. He finally consciousness after a week of his hospital stay
a. obtained
b. restored
c. returned
d. regained

22. You can always
a. plant
b. transplant
c. implant d. transmit

a kidney from a healthy donor.

23. She years ago. the AIDS virus through blood transfusion a few

24. $\mathrm{He}$
a. transplanted
b. transmitted
c. transported
d. attracted infection. a surgical dialysis for his leg to prevent further
a. underwent
b. passed
c. make
d. conducted

25. The doctor asked the patient to take a certain medication three times a day in order to his allergic cough.

26. She
a. depress
b. express
c. suppress
d. dispossess
a. alleviated
c. insulated
d. agitated the pains of

27. A healthy diet should help your body
a. resist
b. reject
c. desist
d. infest infection.

28. the patient medical help
a. brought
b. thought
c. gloat
d. sought

29. He fell down on the stairs and his right ankle.
a. sprained
b. sustained
c. strained
d. drained

30. Metronidazole tablets belong to a group of medicines called anti-infective agents. They may be used to
a. decrease
b. treat
c. diagnose gum and teeth infections.

31. The man a heart attack last week.
a. suffered
b. obtained
c. returned
d. recovered

32. The doctors decided to the patient's hip.
a. reimburse
b. replace
c. relapse
d. reverse

33. The patient was
a. referred
b. related
to a cardiolog
c. admitted
d. designated

check his heartbeat.

34. Mothers should learn different methods to
a. cure
b. blurb
c. curb
d. burp their babies. 
35. It took the nurse 15 minutes to
a. dress
b. suppress
c. caress

the patient's wound.

36. The operation may the patient's life.
a. endanger
b. threat
c. expose
d. distress

37. The surgeon the wound with a scalpel.
a. cut
b. stitched
c. probed
d. cured

38. The old lady her knee on the corner of the dining table.
a. healed
b. bruised
c. squeezed
d. pinched

39. This lotion is expected to the rash within half an hour.
a. smooth
b. damage
c. soothe
d. detect

40. The patient was advised to had started using the medicine. the dosage two weeks after he
a. adjust
b. enlarge
c. amend
d. fix

B. Underline the word or phrase that is not acceptable in each of the following sentences, if any, and correct it.

1. The nurse identified the patients' temperature.

2. Four people rushed the patient inside the hospital.

3. The patient was given a referring letter to a neurologist.

4. The old man died from pneumonia last week.

5. The baby's mother was advised to give her child a syrup to suffocate his dry cough.

6. Three people were sprained in the accident.

7. He cures his asthma with a bronchodilator.

8. The patient was transported to a new hospital.

9. My friend is planning to specialize in alternating medicine.

10. The doctor finally managed to prognose the cause of the illness.

\section{Circle the letter of the correct answer that best fills in the blank in each of the following sentences.}

1. He has recently been diagnosed angina.
a. of
b. from
c. by
d. with

2. She was admitted hospital yesterday but she already left in the afternoon.
a. for
b. into
c. to
d. at

3. It takes an immense energy to bring ___ mucus if you have hiatus hernia.
a. out
b. up
c. outside
d. forth

4. The patient suffered for a long period of time but he finally got his illness.
a. over
b. out of
c. from
d. through 
5. The patient presented grossly swollen ankles and large varicose veins.
a. for
b. against
c. anti
d. with

6. She picked the flu on her way to Thailand.
a. on
b. at
c. out
d. up

7. The parents consented
a. for
b. to
c. with

the surgery.

8. She broke and cried as she described the symptoms to the doctor.
a. up
b. off
c. out
d. down

9. The doctors fully cured her
a. off
b. of
c. out of

the disease within two months.

10. The nurse propped the patient with pillows.
a. out
b. against
c. up
d. with

\section{Match each word in column A with it complement from column B. Write the letter of the correct answer}

beside the word in column $A$.

\begin{tabular}{|l|l|l|}
\hline \multicolumn{1}{|c|}{$\mathbf{A}$} & $\begin{array}{l}\text { Correct } \\
\text { answer }\end{array}$ & $\mathbf{B}$ \\
\hline 1. runny & & a. manners \\
\hline 2. myocardial & & b. genes \\
\hline 3. bedside & & c. nose \\
\hline 4. general & & d. conditions \\
\hline 5. hoarse & & e. infarction \\
\hline 6. defective & & f. anesthesia \\
\hline 7. insanitary & & g. voice \\
\hline 8. premature & & h. report \\
\hline 9. subjective & & i. tumor \\
\hline 10. incipient & & j. infant \\
\hline
\end{tabular}

\section{Production Tasks}

$$
\text { ترجم الجمل الآتية الى اللغة الإنجليزية }
$$

A. Translate the following sentences into English

$$
\begin{aligned}
& \text { 1. يستطيع العاملون في المهن الطبية إعطاء الأدوية للمرضى في الحالات الطارئة. } \\
& \text { 2. قرر الفريق الطبي بثر إصبع المريض. }
\end{aligned}
$$

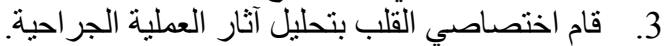

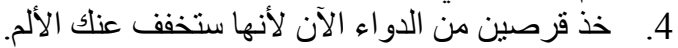

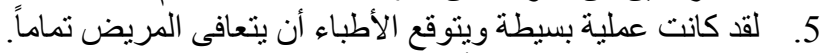

$$
\begin{aligned}
& \text { 6. ستشعر بتحسن عندما يبدأ مفعول المسكنات. }
\end{aligned}
$$

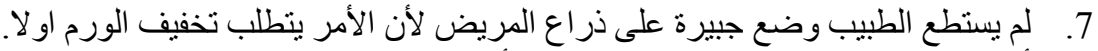

$$
\begin{aligned}
& \text { 8. أصيبت مدرضات عديدات بفيروس كورونا أثناء عملهن في إفريقيا. }
\end{aligned}
$$




$$
\begin{aligned}
& \text { 9. يجرب الأطباء عدة طرق لمعالجة الأمر اض. }
\end{aligned}
$$

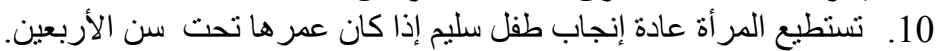

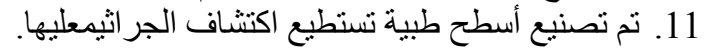

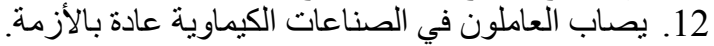

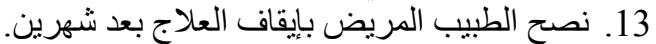

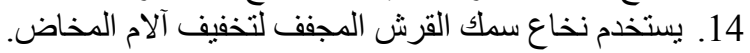

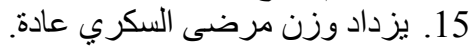

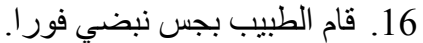

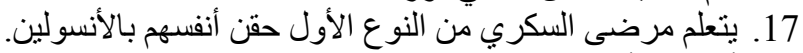

$$
\begin{aligned}
& \text { 18. أجرى الأطباء عملية جر احية لاستئصسال الز ائدة الدودية. }
\end{aligned}
$$

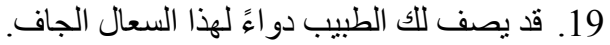

$$
\begin{aligned}
& \text { 20. نتمنى أن تزرع للمريض كلية سليمة. }
\end{aligned}
$$

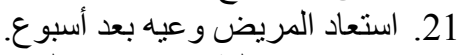

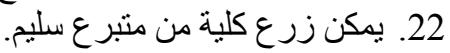

$$
\begin{aligned}
& \text { 23. لقد نقلت المريضة فيروس الايدز في عملية نقل للام. للام. }
\end{aligned}
$$

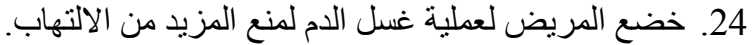

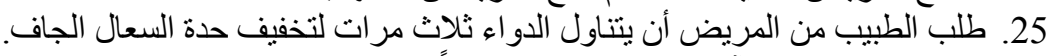

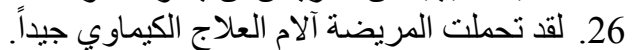

$$
\begin{aligned}
& \text { 27. يساعد النظام الغذائي الجيد الجسم في مقاومة العاج الالتهاب. }
\end{aligned}
$$

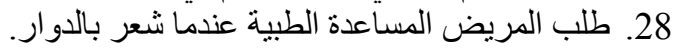

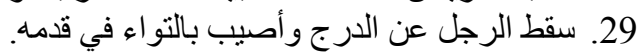

$$
\begin{aligned}
& \text { 30 30 يستخدم هذا الدو اء لمعالجة التهاب اللثة واهب الاسنان. } \\
& \text { 31. 30. أصبي الرجل بجلطة. } \\
& \text { 32. قرر الأطباء استبدال مفصل فخذ الرجة المريض. }
\end{aligned}
$$

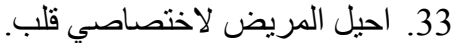

$$
\begin{aligned}
& \text { 34. ينبغي للأم ان تتعلم عدة طرق لإن لمساعدة طفلها على التجشؤ. }
\end{aligned}
$$

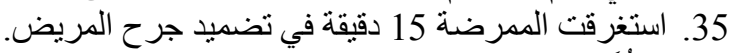

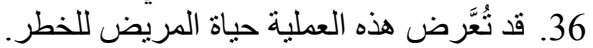

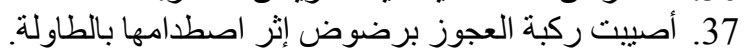

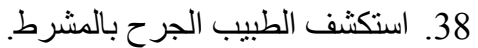

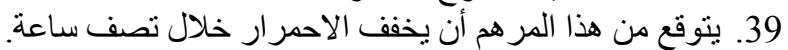

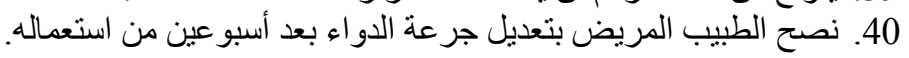

\section{B. Fill in each blank space in the following sentences with the correct word or phrase from the list below.}

\section{administer alleviate make reduce contracted develop probed}

detect receive transplant sprained resist replace dress soothe

1. You can always a kidney from a healthy donor.

2. Take two tablets now. They will the pain quickly.

3. This lotion is expected to the rash within half an hour.

4. He fell down on the stairs and his right ankle.

5. It was a simple recovery and the doctors expected the patient to a full recovery. 
6. Many nurses contracted the corona virus while they were touring camps in Africa

7. People who work in chemical industries usually asthma at an early age.

8. Paramedic crews can drugs to patients in emergency cases.

9. The surgeon probed the wound with a scalpel

10. Hopefully, the patient will a healthy kidney during the transplant.

11. The doctors decided to the patient's hip

12. The doctor could not put the patient's arm in a plaster because he had to the swelling.

13. A healthy diet should help your body

14. It took the nurse 15 minutes to infection

15. They created medical surfaces that can the patient's wound. pathogens.

\section{Fill in each blank space in the following sentences with the correct word or phrase from the list below.}

allergic benign primary defective intermittent lethal acute incipient inoperable predisposed

1. In the 1940s, __ reumatic fever and rheumatic heart disease was as common in Melbourne as it is among indigenous Australians today.

2. Helen has an reaction to the stings of bees.

3.The risk for developing metastatic lesions from cutaneous melanomas increases with tumor thickness.

4. Cf is caused when the gene compels the epithelial cells to generate a protein strain known as CFTR strain or cystic.

5. The young man died because of an tumor.

6. He felt an pain that kept recurring over and over again.

7.There are many conditions that miners to lung disease.

8.In actual fact, for the vast majority of cases, adenoma is a_tumor and self-limiting.

9. There were signs of an tumor in the brain.

10. If so, you may be suffering from Woman's Mind-Reading Syndrome that can be a disease to relationships.

D. Fill in each blank space in the following sentences with the correct preposition from the list below. You may use a preposition more than once if needed.

$$
\text { up to over out of on down }
$$

1. The doctors cured her the disease.

2. The parents consented the surgery. 
3. The surgeon operated the conjoined twins.

4. The nurse propped the patient with pillows.

5. The swelling has started to go

6. He reacted the news of his wife negatively

7. He must have picked the disease when he was travelling in Africa.

8. The patient suffered for a long period of time but he finally got his illness.

9. When we told her that her father was ill, she knocked

10. She became worried when the girl started coughing blood. 